\title{
Enhancing Quality and Efficiency of Public Investment in Vietnam up to 2020
}

\author{
DIEP GIA LUAT \\ University of Economics HCMC - gialuat@ueh.edu.vn \\ DANG VAN CUONG \\ University of Economics HCMC - dangcuong@ueh.edu.vn \\ BUI DUY TUNG \\ University of Economics HCMC - tungbd@ueh.edu.vn
}

\begin{abstract}
ARTICLE INFO
ABSTRACT

Article history:

Based on the theories on quality and efficiency of public investment

Received: and on the ground of a new economic model, this study carries out an

Aug. 272014 analytical assessment of the management of Vietnam's public investment, with the primary aims to detect limitations on Received in revised form: management, carry evaluation of the investment, and propose Jan. 302015 solutions to improving its quality and efficiency. The findings indicate that both the public investment quality and efficiency of Vietnam reveal certain limitations, and no evidence can be found for the Accepted: effectiveness of investment expenditures in short terms, although a

Dec. 302015 long-term relation exists between the public investment and economic growth. A few comprehensive solutions to investment enhancement

Keywords: until 2020 are as follows: (i) Rationally adjusting investment

Public investment, quality, efficiency, structures and portfolios, (ii) Improving institutional environment; (iii) Controlling investment efficiency; and (iv) Modernizing the monitoring system for the public investment.
\end{abstract} ARDL, dynamic OLS. 


\section{Introduction}

In Vietnam public investment plays a significant role in total social investment. Recent years saw its positive contribution in domestic socioeconomic development along with its .beneficial effects, such as on attracting foreign capital investment, promoting rapid economic growth, enhancing living standards of citizens, stabilizing macroeconomic performance, and significantly facilitating poverty reduction. It also contributes to speeding up economic restructuring, creating jobs, and positioning and strengthening the country's economy in its association with regional and world economic systems. However, some discrepancy arises in assessing the quality and efficiency of public investment. Barro (1990) based his research on endogenous growth models to consider government spending, finding that under specific circumstances productive government spending maximizes the growth and welfare. Mandl et al. (2008) suggested that effective assessment focuses on evaluating the success in utilizing resources to achieve the goals. Transmission mechanisms are investments in education, research and development to raise human capital, and new technological advancements, thereby increasing labor productivity and production accordingly (Afonso et al., 2005). Assessing public investment quality also involves measuring its efficiency (Mihaiu et al., 2010). Adopting a theoretical framework to adequately highlight the issues, we attempt to:

(i) Identify the theoretical bases toward public investment efficiency;

(ii) Assess the effectiveness of Vietnam's public investment between 2005 and 2012;

(iii) Empirically examine and/or verify certain contributory factors to reduced efficiency; and

(iv) Propose solutions to reforming institutional and legal frameworks and improving the current status of public investment.

To address the above issues, this study is conducted using statistical data and statements on assessing public investment efficiency besides empirical analyses of public investment and economic growth in an effort to bridge the gap between theoretical and practical concerns over the adoption and implementation of public investment policy. 


\section{Theoretical bases of quality and efficiency of public investment}

\subsection{Theoretical framework for assessing quality and efficiency of public investment}

Concerning the theoretical investigation into public finance and economic growth, Afonso et al. (2005) proposed four key channels, namely: (i) institutional framework (standard definitions of law and regulations); (ii) tax system; (iii) macroeconomic stabilization policies; and (iv) public expenditures (such as investments in education, healthcare services, infrastructure, telecommunication, etc.). A number of fiscal policies are believed to be resulting in long-term growth, which, as regards modern endogenous models, is also contributed to or affected by public spending (Zaler \& Durnecker, 2003).

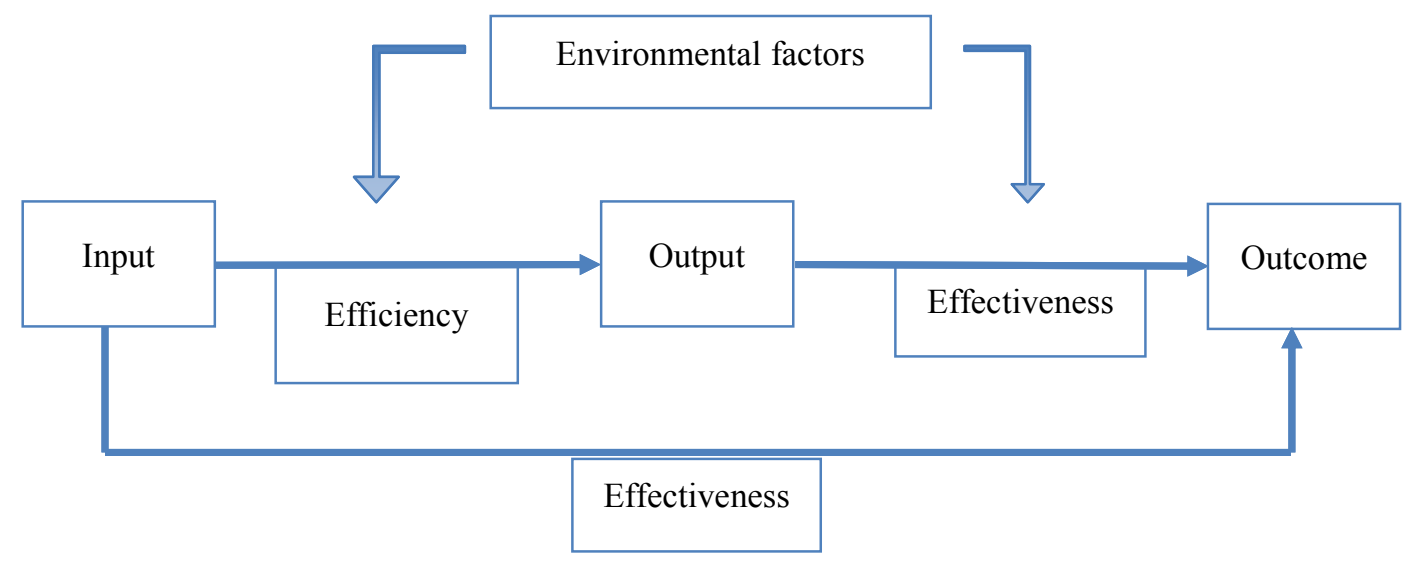

Figure 1. Theoretical framework of efficiency and effectiveness

Source: Mandl et al. (2008)

Public investment effectiveness in principle associates both the input and output to the target to aim for. In the field of public investment the capital sources (input) should be efficiently used to attain multiple growth objectives, thus enhancing people's welfare. These objectives set by the state sector highlight social richness or economic growth, specifically affected by numerous factors (regarded as being exogenous). On account of this link, Mandl et al. (2008) argued that the effectiveness reflects the success in using resources to reach the goals established. It is, however, not at all easy to determine the relation between such input factors as capital or human resources and the achievement of the objectives like growth in GDP per capita. Such a difficulty arises because: (i) public spending and investment should meet multiple objectives concurrently; and (ii) 
non-market goods are mostly provided by the public sector, implying the unavailability of their market value (Mandl et al., 2008).

Quality of public investment is a complex concept, and establishing sufficient criteria for assessing the factor seems to be a challenging task. Estimating public investment quality involves considering whether public products/services satisfy the demands from citizens. In this context the issue of quality also covers effectiveness (Mihaiu et al., 2010).

ECB (2001) maintained that the goals of using public investment funds for economic growth can be achieved through increasing marginal product of capital and labor in the private sector. The government may improve human capital and technology via investments in education and research and development (R\&D), the transmission mechanism of which can be summarized as follows: Investments in educational and R\&D activities increase human capital and facilitates new technological advances, which thus helps raise labor productivity and ultimately production (Afonso et al., 2005). Likewise, other kinds of investments come up with specific transmission channels; however, some may not have any effect on the growth.

In addition, the quality of public expenditure can be regarded through two dimensions: (i) composition of spending; and (ii) effectiveness of policies (Busatto, 2011). Only a few governmental activities and public spending, as stated by Afonso et al. (2005) are essential to economic growth. This kind of 'productive' spending plays a major part in promoting growth just like private capital and labor. If expenditures exert a direct impact on the growth, they are then characterized as being productive, but is considered 'unproductive' otherwise (Barro \& Sala-i-Martin, 1995). Thus, reforming public expenditures to profitable investments would be positively promoting growth rate without an adverse effect whatsoever (Zagler \& Durnecker, 2003).

The theoretical model proposed by Devarajan et al. (1996) allows for effective estimations in accordance with Busatto's (2001) definition by adopting the production function $(y)$ dependent on capital $(k)$ and government expenditures $\left(g_{l}, g_{2}, \ldots\right)$.

$$
y=f\left(k, g_{1}, g_{2}, \ldots\right)=\left[\alpha k^{-\zeta}+\beta g_{1}^{-\zeta}+\cdots\right]^{-1 / \zeta}
$$

Earlier findings indicate that: (i) when changes are made to the structure of government expenditures, growth rate can be improved; and (ii) the expenditures feature 
an optimal proportion (to total expenditures), which would, if exceeded, either impede or adversely affect the growth.

\subsection{Previous studies on quality and efficiency of public investment}

Existing empirical researches focused on the efficiency of public investment in the core sectors such as education and health care services. Moreover, some authors attempted to quantify the losses caused by poor management of public expenditure systems (Leruth \& Paul, 2006). Inefficiency may be partly derived from high costs, including transaction and agency costs. Similar results were obtained in a study of Ghana (Ye \& Sudharshan Canagarajah, 2002), suggesting that $20 \%$ of public health expenditure and $50 \%$ of public education expenditure benefit the right facilities.

The problems arising in measuring public investment efficiency were further addressed in Leruth and Paul's (2006) empirical study of 25 poor countries with high public debt. Most of these countries were suggested to upgrade the efficiency of public expenditure management to control capital investment. The issues of internal management and post-auditing are also to be in contemplation (Leruth \& Paul, 2006).

In developing countries public expenditures, capital accumulation, or economic growth is hindered by low efficiency in public investment. The theories on the trade-offs between public expenditures and capital accumulation assume that public sector investment is effective, which can easily be disproved in low-income countries. Degree of inefficiency, wastefulness, or corruption potentially distorts the impact of public expenditures on the accumulation of capital sources, thereby impairing the efficiency in implementing investment projects.

It is important to identify the quality and efficiency of public investment in order to determine the marginal productivity of investment as well as its effect on growth. Barro (1990), based on an endogenous growth model, found that effective public expenditure raises long-term growth by increasing returns on production factors. Inefficiencies and corruption in public infrastructure investment reduces the quality and effectiveness of public capital, negatively affecting the motives for firms' investment (Chakraborty \& Dabla-Norris, 2009). Investment decisions are made in broader institutional frameworks, and the quality of adopting, managing, and implementing investment projects plays a major role when measuring returns on capital (Esfahani \& Ramirez, 2003; Haque \& Kneller, 2008; Flyvbjerg et al., 2003). High costs, wastefulness, and low fulfilment rates frequently recorded in key infrastructure projects in developing countries may 
negatively influence the adoption, moderation, and evaluation. Remarked by Collier (2008), investment returns in low-income countries are limited by information and technical capacity in assessing the feasibility of projects, as well as corruption and bribery. Investment in the public sector, especially in infrastructure development, is significantly associated with not merely economic but also political issues. Interest group pressure and the structure of political institutions have impacts on infrastructure deployment (Henisz \& Zelner, 2006). A bad regulatory framework has a tendency to bring about increasing political interference and disable the anticipation of mid-term results (Guasch et al., 2007), which is often seen in countries with low income levels.

Empirical studies on public investment with its impact focused on analyzing the longterm nexus with growth in total production or productivity. Most findings indicated the positive relation, notably in public infrastructure investment, and so did those of recent works, using qualitative indicators of infrastructure adequacy as proxies for infrastructure quality.

Others on the structure of public expenditures also provided empirical evidence of its effects on growth. Aschauer (1989) suggested that one major component positively affecting growth is investment expenditure. The findings from Barro (1990), Easterly and Rebelo (1993), and Devarajan et al. (1996) concluded the positive influence of physical capital accumulation on growth rate. However, in view of Afonso et al.'s (2005) arguments, whether the investment expenditure is "productive" depends on the project itself as well as its institutional framework.

Contributory elements to economic growth also comprise investments in human capital and research and development (Romer, 1990), in security of property rights (Keefer \& Knack, 2002), in education (Barro, 1991), and in healthcare services (Kneller et al., 1999; Bloom et al., 2001).

In short, previous investigations highlight the crucial importance of increasing public investment in developing countries, and its impact on economic growth heavily depends on its quality as well as efficiency.

\subsection{Research models of public investment quality and efficiency}

Efficiency in using invested capital can be assessed through the relation between total government spending and economic growth. On the ground of previous findings, we compile the ARDL and cointegration testing for the variables via the 
bound testing approach as advanced by Pesaran et al. (2001). The approach offers three following advantages: (i) applicable to a set of variables at I(0) and I(1); (ii) convenient for result testing by employing one single equation; and (iii) applicable to variables with different lags.

Regarding the issue, we adopt Loizides and Vamvoukas's (2005) technique, presented as below:

$$
\Delta Y_{t}=\beta_{0}+\lambda E C+\sum_{i=1}^{p} \beta_{1} \Delta Y_{t-i}+\sum_{j=1}^{q} \beta_{2} \Delta X_{t-j}+\varepsilon_{t}
$$

where $Y$ is $\log$ of GDP, $\lambda$ is vector of short-run adjustment coefficient, $E C$ is errorcorrection terms in equation of cointegration between GDP and investment expenditure, $X$ is log of investment expenditure, and $\varepsilon$ represents exogenous shocks.

Also, to test for efficiency of different kinds of public capital, we follow approaches as earlier employed by Devarajan et al. (1996), Busatto (2011), and Singh and Weber (1997). The following equation also highlights government expenditures on GDP:

$$
Y_{t}=\beta_{0}+\beta X+\sum_{j=-q}^{p} d_{j} \Delta X_{t-j}+u_{t}
$$

where $Y_{t}$ is GDP, $X$ is a vector including variables of proportions of government expenditures to total investment.

Proposed by Stocked and Watson (1993) and utilized in this study, dynamic OLS technique improves OLS estimations, applied to a small sample size along with dynamic sources of bias. Although the Jahansen's method is deemed as informative, results of one equation may be negatively affected by wrong measurements in others. On the contrary, Stock and Watson's estimator centers on the sole equation, yet ensures the robustness and, by adding to it different leads and lags, overcomes the problem of endogeneity. The method, moreover, has similar asymptotic optimality properties to the Johansen distribution (Al-Azzam \& Hawdon, 1997). Finally, to handle spurious regressors, unit root tests will be performed for the error terms (Choi et al., 2008). 


\section{Assessing quality and efficiency of Vietnam's public investment}

\subsection{The current state of public investment in Vietnam}

From 2010 and before, public investment accounted for large proportions, but the state investment became less significant after 2010 (as compared to non-state investment). Differences in the two types, despite not being great, display a shift in the structure of social capital investment.

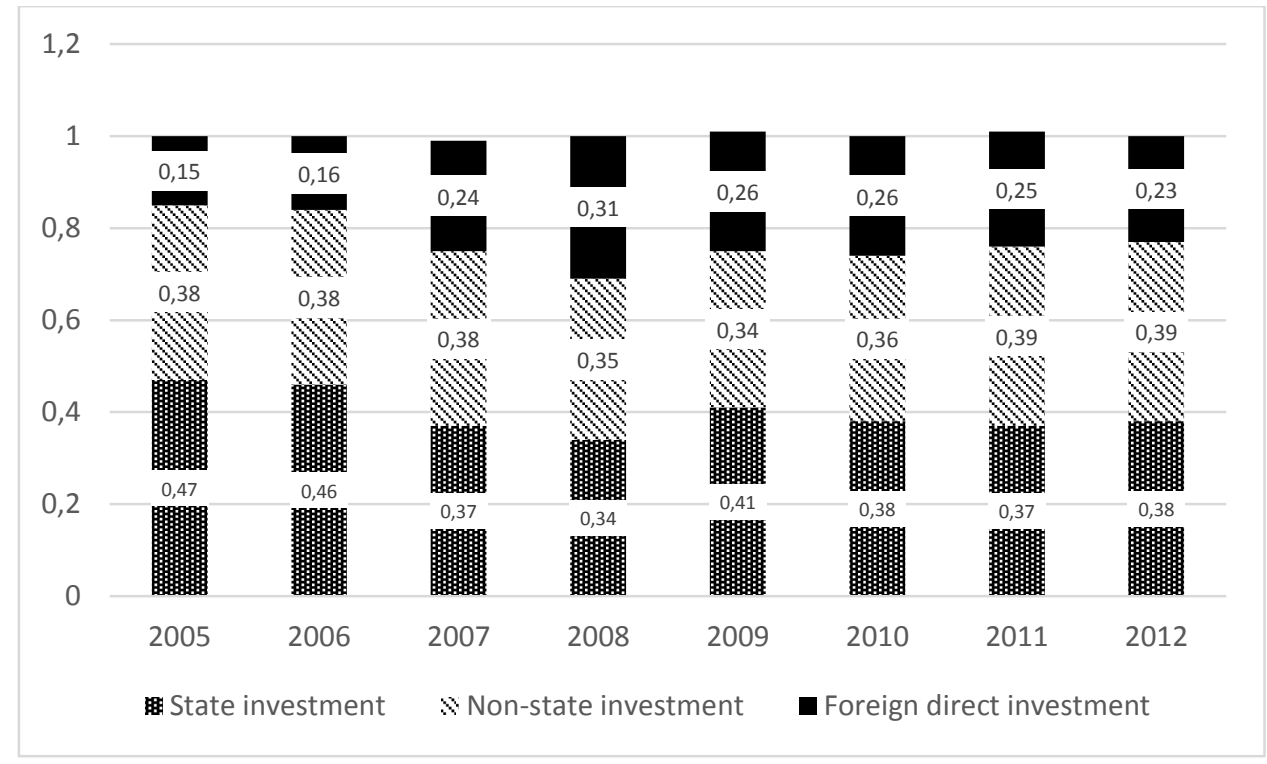

Figure 1. Structure of capital investment in Vietnam for 2005-2012 (in VNDbillion and real prices)

Source: authors' compilation from Ministry of Planning and Investment's statistics

For the period of 2005-2010 annual growth rates of public investment range between $0.34 \%$ and $0.47 \%$. Investments in different sectors, however, reflected huge differences, and their proportions varied over each year. Accounting for the largest proportion was investment in economic sector (of above 70\%), whereas that in social domains (healthcare, education, and socio-cultural activities) made up no more than $20 \%$ and was in a declining trend (at time reaching the lowest rate of about 15\%). The rates of investment expenditures on the agriculture, forestry, and fishing industry, as a branch of that in economic development, revealed constant reduction from $12.2 \%$ in 2000 to $6.1 \%$ in 2010 . 


\subsection{Evaluating Vietnam's public investment by two criteria}

Reports by moderating agencies on the quality and efficiency of Vietnam's public investment reveal the following issues:

The state investment issue has become one primary motivation for stimulating growth and the process of economic reforms over the past years, encompassing projects on transport infrastructure development which triggered widespread effects on the economy. Positive shifts in the structure of public expenditures include: (i) enhancing public infrastructure investment for improvements in investment climate and growth rate in addition to redressing regional inequality; (ii) further investing in key sectors with competitive advantages; and (iii) laying more emphasis on developing human resources and sharpening labor skills. Constructing legal frameworks is found to be in unity in modifying both overall investment in general and state investment in particular. The legal system has in principal been covering most of the state investment projects besides closer monitoring in increasing extent. In 2011 the number of projects to have been put under control was 398, out of the total of 481 investment schemes, reaching the higher rate of $82.74 \%$, compared to $62.58 \%$ and $58.8 \%$ as in 2010 and 2009 respectively. Thus, the supervision has significantly allowed for prompt detection of and adjustment to basic flaws in public investment. Improvements in final settlements of capital investment accounts would be noticed in spite of a rather high level of completed projects with no sufficient settlements.

Public investment in Vietnam, apart from substantial gains, reveals certain shortcomings, and to this respect these can be addressed from definition-related aspects. First, the investment has not clearly exhibited its roles and characteristics, thereby causing the incident of unconcentrated, scattering investment crowding out private sector investment. Second, if the public investment is viewed as a common kind of spending, its benefits are then scarcely living up to expectations. In terms of its characteristics, we now see no noticeable difference between state and non-state investment types. The former may interfere in the arenas in which the latter may be involved.

Most current public expenditures are not beneficial as expected. On the macro level, although the amount of public capital investment was increasing, the growth of GDP was not significant. This is easily identifiable by the ICOR related to investment effectiveness of the public sector and the entire economy. Public sector investment, 
despite making up a large proportion, brought little efficiency in terms of the ICOR. During the period from 1996 to 2012, the public sector's ICOR was constantly higher than the average rate of the whole economic sector.

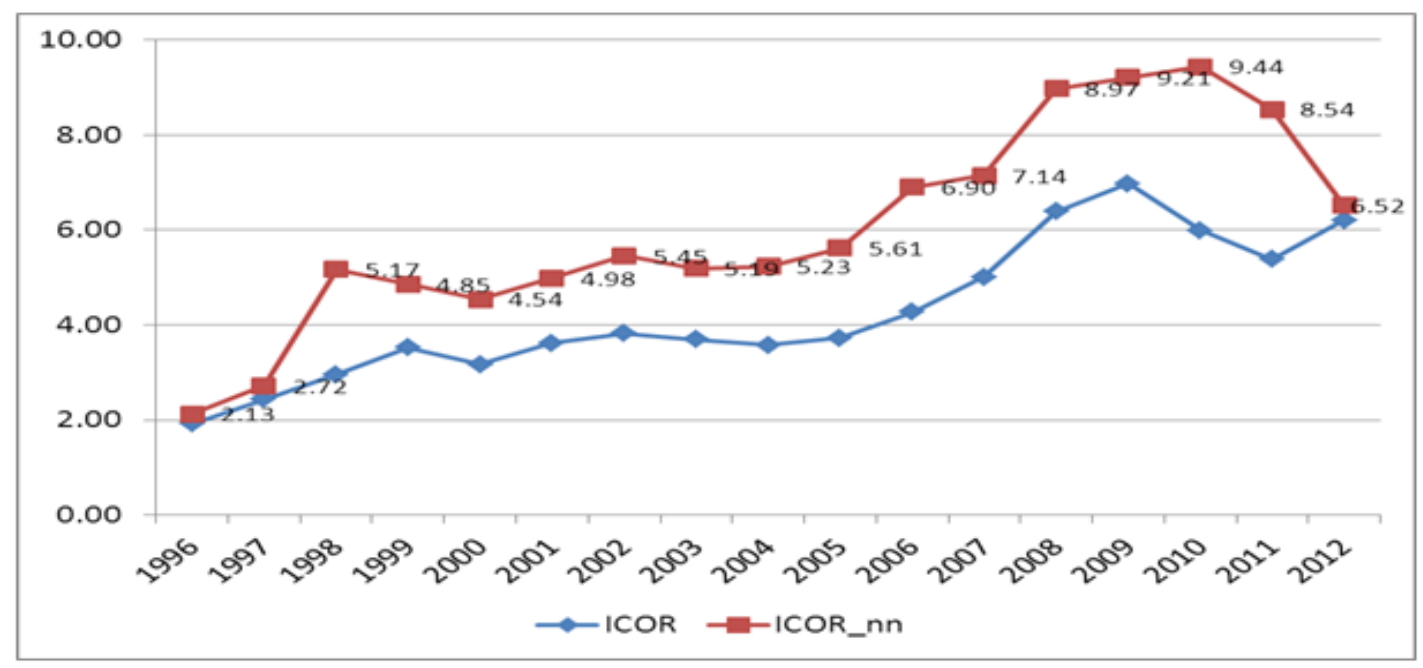

Figure 2. ICOR of public sector and the whole economy during the 1996-2012 period Source: authors' compilation from GSO

Public investment projects themselves have not been remarkably effective; capital recovery for some completed projects was not as originally planned. Typically, a few construction projects imposed charges, but after many years of operation the fees collected were not even sufficient for maintenance or renovation of construction sites. Consequently, their quality would not be guaranteed, and hardly would beneficiaries feel satisfied with investment outcomes.

Implementation of public investment projects has been stagnant, entailing increased costs and reduced efficiency. Specifically, in 2010 the number of behind-schedule projects was 3,386 , accounting for $16.6 \%$ of evaluating and monitoring projects, among which the rate of behind-schedule ones resulting from site clearance and capacity of investors, project managers, and contractors were $39.72 \%$ and $20.23 \%$ respectively; this figure for the year 2011 was 4436 (33.65\%), besides a few works which lasted from five to seven years. Increasing rates of project adjustments not only led to rising investment costs but also affect the progress and/or duration of the project; limited or selective tendering grew as large proportions, whereas loopholes in bidding regulations have not been rectified (Vo, 2013). 
The following reasons for the aforementioned issues shall be regarded:

First, public investment management in general, including the inspection and supervision of capital construction investment, is in slow progress; supervision processes approached by input indicators are costly but with low efficiency. The focus of inspection and auditing agencies has been on the issues of compliance with spending quotas and regimes. Estimated costs of the projects are based on these spending quotas and regimes established by the State, which are, nevertheless, often outdated or incomplete, and so are often being capitalized to push up estimated costs. These are then submitted to senior authorities for approval, succeeded by limited or selective tendering.

Second, input-based approaches let the agencies take excessive account of procedures, sequences, or project spending regimes or quotas, and so on, instead of its objectives and effectiveness.

Third, the roles of citizens, political institutions, and other social organizations like independent auditing and independent advisory and supervisory agencies have not been well promoted. Additionally, there has been a lack of well-defined responsibilities of publicized information providers dependent on whom Government's policies would conveniently be grasped by a large number of people. The oversight role of democratically elected agencies is not amply fulfilled, and a low rate of officers-incharge has badly affected the quality of supervision.

Fourth, managerial work boldly features the ask-and-grant mechanism, even though there has been implementation of decentralization and autonomy granted to investors and/or subordinators. All procedures are to be inspected and approved; hence, it is difficult to ascribe responsibilities in case of fault detection.

Fifth, inspectors' and supervisors' capabilities are limited, thus hardly meeting current financial management requirements. Insufficient information on targets to be inspected and loose connection and/or lack of coordination between agencies should be evident.

Sixth, state regulations on management of basic investments are too complicated and lacking in transparency, thereby causing multiple interpretations and hampering subsequent implementation.

Last, in organizing supervision agencies the independence and clear scope of operation have yet to be achieved. This involves mass participation yet little chance in claiming responsibilities. 


\section{Empirical checks on public investment efficiency}

This study uses ADB's statistics and empirically examines the efficiency in invested capital use of Vietnam. The dataset covers Vietnam's state public expenditure and gross domestic product statistics over the period of 1986-2002.

\section{Table 1}

Statistical description of variables used to assess invested capital efficiency

\begin{tabular}{lllllll}
\hline Variable & Obs. & Mean & Std. dev. & Min & Max & Source \\
\hline GDP in logarithm & 27 & 12.43469 & 2.047861 & 6.395262 & 14.99275 & ADB \\
\hline Public investment expenditure in logarithm & 27 & 9.703562 & 2.259734 & 3.496508 & 12.24676 & ADB \\
\hline
\end{tabular}

\section{Stationarity testing}

Our test on data stationarity demonstrates that: (i) GDP is nonstationary with and without trend at level for the three significance levels of $1 \%, 5 \%$, and $10 \%$; (ii) State investment expenditure is nonstationary without trend at three significance levels, but is stationary with trend at $10 \%$ level; and (iii) the two variables at first differences are stationary both with and without trend.

\section{Table 2}

Stationarity testing for variables at level and first differences

\begin{tabular}{lcc}
\hline \multirow{2}{*}{ Variable } & \multicolumn{2}{c}{ ADF statistics } \\
\cline { 2 - 3 } & Without trend & With trend \\
\hline GDP in logarithm - Ln(GDP) & 1.3 & -1.126 \\
Investment expenditure in logarithm - Ln(CAE) & -1.64 & $-3.346^{*}$ \\
First difference of $\operatorname{Ln}(\mathrm{GDP})$ & $-3.31^{* *}$ & $-3.49^{* *}$ \\
First difference of $\operatorname{Ln}(\mathrm{CAE})$ & $-4.739^{* * *}$ & $-4.369^{* * *}$ \\
\hline
\end{tabular}

Note: MacKinnon critical values for rejection of hypothesis of a unit root at $1 \%(* * *), 5 \%(* *)$, and $10 \%(*)$ significance levels

As for this result, no variable is I(2). We thus rely on cointegration approach proposed by Pesaran et al. (2001) by initially assuming the following unrestricted regression:

$$
\Delta Y_{t}=\beta_{0}+\sum_{i=1}^{p} \beta_{1} \Delta Y_{t-i}+\sum_{j=1}^{q} \beta_{2} \Delta X_{t-j}+\alpha_{1} Y_{t-1}+\alpha_{2} X_{t-1}+v_{t}
$$


The above unrestricted model can be measured by simple OLS, followed by a test on $v_{t}$. If no autocorrelation and heteroskadasticity is found for the case of $v_{t}$, we continue with marginal tests suggested also by Pesaran et al. (2001) with the null hypothesis: $H_{0}: \alpha_{1}=\alpha_{2}=0$. If the results achieved from these indicate cointegration between the variables, Eq. (*) will then be used to examine short- and long-run relations of the variables in the model.

\section{Table 3}

Cointegration testing with marginal approach

\begin{tabular}{lcccccc}
\hline & $\mathrm{I}(0)$ & $\mathrm{I}(1)$ & $\mathrm{I}(0)$ & $\mathrm{I}(1)$ & $\mathrm{I}(0)$ & $\mathrm{I}(1)$ \\
& Lower & Upper & Lower & Upper & Lower & Upper \\
& $10 \%$ & $10 \%$ & $5 \%$ & $5 \%$ & $1 \%$ & $1 \%$ \\
\hline $\mathrm{K}=1$ & 4.04 & 4.78 & 4.94 & 5.73 & 6.84 & 7.84 \\
\hline F-statistic & 25.17 & & & & & \\
\hline
\end{tabular}

Tables 3 and 4 display the results of testing for cointegration with $\mathrm{R}_{2}$, Breusch Pagan test for heteroscedasticity, and Breusch-Godfrey test for autocorrelation, suggesting that it is inappropriately restricted or no evidence can be found of the problems of heteroscedasticity and autocorrelation. The testing results based on Pesaran et al.'s (2001) marginal approach demonstrate that F-statistic is larger than all critical values at the three significance levels. Thus, a long-run nexus can be concluded between investment expenditure and growth, based on which we proceed with restricted regression of $(*)$.

\section{Table 4}

Results of model testing

\begin{tabular}{lcccc}
\hline Dependent variable: log-differenced GDP & & & \\
\hline & $\begin{array}{c}\text { Unrestricted } \\
\text { ARDL }\end{array}$ & $\begin{array}{c}\text { Restricted } \\
\text { ARDL }\end{array}$ & First model & $\begin{array}{c}\text { Second } \\
\text { model }\end{array}$ \\
\hline L1. Log GDP & $-0.430^{* * *}$ & & \\
L1. Log investment expenditure & $0.416^{* * *}$ & & & \\
L1. Error correction & & $-0.468^{* * *}$ & $-0.460^{* * *}$ & $-0.487^{* * *}$ \\
L3. Log-differenced GDP & $0.712^{* * *}$ & $0.718^{* * *}$ & $0.626^{* * *}$ & $0.709^{* * *}$
\end{tabular}


Dependent variable: log-differenced GDP

\begin{tabular}{|c|c|c|c|c|}
\hline & $\begin{array}{l}\text { Unrestricted } \\
\text { ARDL }\end{array}$ & $\begin{array}{l}\text { Restricted } \\
\text { ARDL }\end{array}$ & First model & $\begin{array}{l}\text { Second } \\
\text { model }\end{array}$ \\
\hline L5. Log-differenced GDP & $0.186^{* * *}$ & $0.136^{* *}$ & $0.169 * * *$ & $0.155^{* * *}$ \\
\hline $\begin{array}{l}\text { L1. Log-differenced investment } \\
\text { expenditure }\end{array}$ & $-0.344 * * *$ & $-0.345^{* * *}$ & $-0.343^{* * *}$ & $-0.360 * * *$ \\
\hline $\begin{array}{l}\text { L2. Log-differenced investment } \\
\text { expenditure }\end{array}$ & $-0.207 * * *$ & $-0.243 * * *$ & $-0.198 * * *$ & $-0.239 * * *$ \\
\hline Dummy variables & & & $-0.0327^{*}$ & $-0.0493 * *$ \\
\hline Intercept & $1.358 * * *$ & $0.094 * * *$ & $0.114 * * *$ & $0.134 * * *$ \\
\hline R-squared & 0.909 & 0.8289 & 0.8662 & 0.8882 \\
\hline Adjusted R-squared & 0.870 & 0.7719 & 0.8088 & 0.8402 \\
\hline \multicolumn{5}{|l|}{ Breusch-Godfrey test } \\
\hline Prob $>\operatorname{chi}^{2}($ lag-1) & 0.538 & 0.1716 & 0.7895 & 0.8408 \\
\hline Prob $>$ chi $^{2}$ (lag-2) & 0.561 & 0.2721 & 0.5201 & 0.7734 \\
\hline Prob $>\operatorname{chi}^{2}($ lag-3) & 0.480 & 0.4454 & 0.5410 & 0.7935 \\
\hline Prob $>$ chi $^{2}$ (lag-4) & 0.101 & 0.5370 & 0.1867 & 0.8918 \\
\hline Breusch-Pagan/Cook-Weisberg test & 0.554 & 0.4214 & 0.5792 & 0.6855 \\
\hline
\end{tabular}

Note: $(* * *),(* *)$, and $(*)$ denote significance levels of $10 \%, 5 \%$, and $1 \%$, and $\mathrm{L} \#$ denotes corresponding lag.

The ARDL test results show that concerning the coefficients of error correction term (statistically significant at $1 \%$ level.), the short-term gap between investment expenditure and sustainable economic growth is $54 \%$. The difference from long-term equilibrium between economic growth and investment expenditure is adjusted in short terms. Furthermore, the regression coefficients of investment expenditure are significant but carry negative signs, implying that in the short run public expenditures have no significant impact on growth rates.

Empirical evidence shows that: (i) long-term relation exists between investment expenditure and economic growth; (ii) public investment expenditure can be employed 
as a means to give rise to growth; (iii) in the short run, nevertheless, there is a negative expenditure-growth association; and (iv) the difference from the equilibrium point is settled in short terms.

In addition, to contrast the efficiency in investment expenditure in difference terms, we further introduce dummy variables to the models. For the first one we opt for the year 2005, when Law No. 59/2005/QH11 on investment was issued, to categorize observations into groups, whereby the ones in 2005 and before take the value of 1 , and 0 otherwise. For the second model we choose the year 2009 to take similar steps when Decree No. 113/2009/ND-CP by the Government on investment monitoring and evaluation took effect. The signs and significance levels of dummy variables indicate that increasing public capital investment impacts more on economic growth for the years after promulgation of legal documents, implying that the promulgation has offered favorable conditions for improving public investment efficiency in the surveyed period.

Evaluating public investment efficiency

As discussed above, we use the following equation as were employed by Devarajan et al. (1996), Busatto (2011), and Singh and Weber (1997), including government expenditures on GDP

$$
Y_{t}=\beta_{0}+\beta X+\sum_{j=-q}^{p} d_{j} \Delta X_{t-j}+u_{t}
$$

where $Y_{t}$ is GDP, $X$ is a vector including variables of proportions of government expenditures to total investment.

Particularly selected are the data for the period between 1990 and 2010 on fractions of government expenditures on education, healthcare services, transportation and telecommunication, mineral exploitation, and so on. 


\section{Table 5}

Statistical description of variables used to assess invested capital efficiency in different fields

\begin{tabular}{lccccc}
\hline Variable & Obs. & Mean & $\begin{array}{c}\text { Std. } \\
\text { dev. }\end{array}$ & Min & Max \\
\hline $\begin{array}{l}\text { Log expenditure on education } \\
\begin{array}{l}\text { Log expenditure on healthcare } \\
\text { services }\end{array}\end{array}$ & 21 & 12.0490 & 0.7654 & 10.8913 & 13.9779 \\
$\begin{array}{l}\text { Log expenditure on transportation and } \\
\text { telecommunication }\end{array}$ & 21 & 3.64489 & 0.5238 & 2.8056 & 4.9177 \\
$\begin{array}{l}\text { Log expenditure on mineral } \\
\text { exploitation }\end{array}$ & 21 & 21.5968 & 3.2346 & 14.2749 & 25.8277 \\
\begin{tabular}{l} 
Log GDP \\
\hline
\end{tabular} & 21 & 4.8237 & 0.4457 & 4.0899 & 5.5212 \\
\hline
\end{tabular}

Source: authors' compilation from IFPRI's statistics

\section{Table 6}

Results of public investment efficiency testing based on DOLS

\begin{tabular}{lc}
\hline Variable & Log GDP \\
\hline Investment in healthcare services & -0.2245 \\
F1. Differenced investment in healthcare services & $0.7340^{* *}$ \\
L1. Differenced investment in healthcare services & 0.027 \\
\hline Investment in education & $0.5628^{* * *}$ \\
F1. Differenced investment in education & 0.1338 \\
L1. Differenced investment in education & -0.1662 \\
\hline Investment in transportation and telecommunication & $0.0894 * * *$ \\
L1. Differenced investment in transportation and telecommunication & $-0.0814 * *$ \\
\hline Investment in mineral exploitation & -0.0146 \\
F1. Differenced investment in mineral exploitation & -0.0229 \\
L1. Differenced investment in mineral exploitation & -0.0178 \\
\hline Constant & -2.3472 \\
\hline
\end{tabular}




\begin{tabular}{lcc}
\hline Variable & Log GDP \\
\hline R-squared & & 0.9574 \\
\hline Adjusted R-squared & 0.8794 \\
\hline Breusch-Godfrey test & Prob $>$ chi $^{2}$ & 0.7379 \\
\hline Breusch-Pagan/Cook-Weisberg test & Prob $>$ chi $^{2}$ & 0.5635 \\
\hline
\end{tabular}

Note: $(* * *),(* *)$, and $(*)$ denote significance levels of $10 \%, 5 \%$, and $1 \%$, and $\mathrm{L} \#$ denotes corresponding lag.

\section{Table 7}

Stationarity test on residuals based on DOLS

\begin{tabular}{|c|c|c|c|}
\hline & \multirow{2}{*}{ Variable } & \multicolumn{2}{|c|}{ ADF-statistics } \\
\hline & & Without trend & With trend \\
\hline Residual & & $-3.30 * *$ & $-3.24 *$ \\
\hline
\end{tabular}

Note: MacKinnon critical values for rejection of hypothesis of a unit root at $1 \%(* * *)$ and $5 \%(* *)$ significance levels

Given various tests on heteroskedasticity and autocorrelation, the null hypothesis cannot be rejected. The results of stationarity test on residuals suggest that they are stationary without trend and with trend at significance levels of $5 \%$ and $10 \%$ respectively.

The DOLS-based regression results indicate that: (i) a negative long-run relation is held between investment in healthcare services and the dependent variable, but its coefficient is not statistically significant; and (ii) investment in education exhibits efficiency in terms of signs and significance of regression coefficients. These two results are compatible with those of Devarajan (1996) and Singh (1997) yet are not with Busatto's (2011) findings.

Accordingly, the effectiveness of public investments in healthcare services and education is not consistent among various economies. Public infrastructure investment, realized through expenditures on telecommunication and transportation, reflect its positive association, consistent with Easterly and Robelo's (1993) results but inconsistent with those of Devarajan (1996) and Busatto (2011). Investment in mineral exploitation, additionally, is not effective as expected; its regression coefficients take negative signs and are not statistically significant. 


\section{Conclusion and policy implications}

\subsection{Conclusion}

Public investment quality is such a sophisticated concept; it is thus difficult to construct adequate assessment indicators, and unsurprisingly, evaluating the quality of its also involves measuring its efficiency. Following the theories on capital investmenteconomic growth association with the use of ARDL and dynamic OLS approaches as advanced by Perasan et al. (2001) and Stock and Watson (1993) respectively, we illustrate that:

(i) Public expenditure in Vietnam is perceived as being important to total public capital investment, and in the long-run scale is associated with growth;

(ii) Promulgation of legal documents has indeed provided favorable conditions for improving public investment efficiency;

(iii) Public investments in education, healthcare services, and infrastructure development exert positive impacts; and

(iv) No corresponding effects are produced by investment in mineral exploitation.

\subsection{Policy implications:}

In the field of public investment it is necessary to:

- Focus on infrastructure development as one of the three major breakthroughs in social development strategies for 2011-2020;

- Aim resources allocation and mobilization at certain areas where non-state sector generates low efficiency in its performance;

- Prioritize strategic implementation over each period when planning the allocation and use of financial resources; and

- Enforce finance-related discipline and financial efficiency and effectiveness besides enhancing transparency and publicization.

It is also imperative that governmental agencies:

(i) concerning improvements in public investment climate

- Innovate decentralizing mechanism and management of public capital toward adequate approval and inspection by central agencies of state-funding projects, which confines uncontrolled project launch by local ones; 
- Upgrade the planning quality by attracting widespread attention of scholars in domestic and international public investment and consulting experts about technical experience in appropriate areas;

- Transform the common growth model to intellect- and technology-based intensive development approaches;

- Alter public investment regimes in congruence with national development strategies by initially considering centralization of strategic long-term planning, then introducing changes to the current mechanism of decentralized investment decisions, and finally ensuring the presence of one which fosters the transparency and publicization of public investment projects; and

(ii) concerning improvements in public investment efficiency until 2020

- Orient public expenditure strategies to development of infrastructure, science and technology, and healthcare training as these foster domestic and foreign investments, enhancing people's welfare and living standards;

- Stimulate a shift from private to public investment portfolios with the participation of private sector, positively contributing to efficiency in capital use, creativity, and project management effectiveness, which is also part of public private partnership;

- Make selection and flexible and coordinative use of criteria for assessing public investment efficiency, that is, relate NPV, IRR, and ICOR or duration of capital recovery and sensitivity analysis to new institutional economics-based (NIE) evaluation frameworks in order to reduce investment costs, enhance political and social accountability, and improve community welfare and equality; and

(iii) concerning innovation in public investment monitoring system

- Adjust regulations on public investment in accordance with advanced systems that promote the role of independent supervisory agencies; adopt design-based tendering, a popular world-wide approach, whereby contractors do not have to follow ceiling prices, or state-approved quotas and norms, yet are entitled to make the appropriate solutions based on assigned technical standards and then to propose rational project amounts;

- Develop criteria for monitoring and measuring public investment risks and information systems and data analysis/assessment meeting inspection or supervision requirements in addition to management of basic construction investment of the state budget in line with criteria of budget management by output control; and 
- Devise information systems and new technologies to capture the monitored targets with the sharing and coordination in information distribution among managerial agencies by using effective, proactive application approaches

\section{References}

Ablo, E., \& Ritva R. (1998). Do budgets really matter? Evidence from public spending on education and health in Uganda (World Bank Policy Research Working Paper No. 1926). Washington, DC: World Bank Group.

Afonso, A., Schuknecht, L., \& Tanzi, V. (2005). Public sector efficiency: An international comparison. Public Choice, 123(3-4), 321-347.

Agenor, R. (2000). The economics of adjustment and growth. San Diego, CA: Academic Press.

Al-Azzam, A., \& Hawdon, D. (1997). Esimating the demand for energy in Jordan: A Stock-Watson dynamic OLS (DOLS) approach. Retrieved from https://www.surrey.ac.uk/economics/ files/apaperspdf/SEED\%2097.pdf

Allen, R., \& Tommasi, D. (2001). Managing public expenditure: A reference book for transition countries. Paris, France: OECD Publishing. doi: http://dx.doi.org/10.1787/9789264192607-en

Andre, L., Guasch, J. L., \& Azumendi, S. L. (2007). Regulatory governance and sector performance: Methodology and evaluation for electricity distribution in Latin America (World Bank Policy Research Working Paper No. 4494). Washington, DC: World Bank Group. doi: http://dx.doi.org/10.1596/1813-9450-4494

Aschauer, D. A. (1989). Does public capital crowd out private capital? Journal of Monetary Economics, 24(2), 171-188.

Bacha, E. L. (1990). A three-gap model of foreign transfers and GDP growth rate in developing countries. Journal of Development Economics, 32, 279-296.

Barro, R. J. (1990). Government spending in a simple endogenous growth model. Journal of Political Economy, 98(5), 103-125.

Barro, R. J. (1991). A cross-country study of growth, saving, and government. In J. D. Bernheim \& J. Shoven, National saving and economic performance (pp. 271-304). Chicago, IL: University of Chicago Press.

Barro, R. J., \& Sala-i-Martin, X. (1995). Economic growth. New York, NY: McGraw-Hill.

Bloom, D. E., Canning, D., \& Sevilla, J. (2001). The effect of health on economic growth: Theory and evidence (NBER Working Paper No. 8587). Cambridge, MA: National Bureau of Economic Research. 
Briceno-Garmendia, C., Karlis Smits, \& Foster, V. (2008). Financing public infrastructure in SubSaharan Africa: Patterns and emerging issues (AICD Background Paper 15). Washington, DC: World Bank Group.

Busatto, L. M. (2011). The quality of public expenditure and its influence on economic growth: evidences from the State of Rio Grande do Sul (RS). Washington, DC: The Institute of Brazilian Issues.

Calderón, C., \& Servén, L. (2008). Infrastructure and economic development in Sub-Saharan Africa. (World Bank Policy Research Working Paper No. 4712). Washington, DC: World Bank Group.

Calderón, C., Odawara, R., \& Servén, L. (2008). Infrastructure investment in developing countries: A quarter-century retrospective (Unpublished manuscript).

Chakraborty, S., \& Dabla-Norris, E. (2009). The quality of public investment (IMF WP/09/154). Washington, DC: International Monetary Fund.

Coase, R. H. (1937). The nature of the firm. Economica (new series), 4(16), 386-405.

Collier, P., \& Venables, A. (2008). Managing resource revenues: Lessons for low income countries. African Economic Research Consortium 2008 Annual Conference.

Dabla-Norris, E., Brumby, J., Kyobe, A., Mills, Z., \& Papageorgiou, C. (2011). Investing in public investment: An index of public investment efficiency (IMF Working Paper. No. 1137). Washington, DC: International Monetary Fund.

DeHoog, R. (1990). Competition, negotiation, or cooperation. Administration and Society, 22(3), $317-340$

Devarajan, S., Swaroop, V., \& Zou, H. F. (1996). The composition of public expenditure and economic growth. Journal of Monetary Economics, 37(2), 313-344.

Diamond, J. (2006). Budget system reform in emerging economies: The challenges and the reform agenda (IMF Occasional Paper No. 245). Washington, DC: International Monetary Fund.

Easterly, W., \& Rebelo, S. (1993). Fiscal policy and economic growth. Journal of Monetary Economics, 32(3), 417-458.

Easterly, W., Irwin, T., \& Serven, L. (2008). Walking up the down escalator: Public investment and fiscal stability. World Bank Research Observer, 23, 37-56.

Esfahani, H., \& Ramirez, M. (2003). Institutions, infrastructure, and economic growth. Journal of Development Economics, 70, 443-477.

Ferris, J., \& Graddy, E. (1998). A contractual framework for new public management theory. International Public Management Journal, 1(2), 225-240.

Flyvbjerg, B., Bruzeliua, N., \& Rothengatter, W. (2003). Megaprojects and risk: An anatomy of ambition. Cambridge, UK: Cambridge University Press.

Guasch, J. L., Laffont, J., \& Straub, S. (2007). Concessions of infrastructure in Latin America: Government-Led renegotiation. Journal of Applied Econometrics, 22, 1267-1294. 
Haque, M., \& Kneller, R. (2008). Public investment and growth: The role of corruption (Research Discussion Paper No. 98). Manchester, UK: Centre for Growth and Business Cycle, The University of Manchester.

Henisz, W. J., \& Zelner, B. A. (2006). Interest groups, veto points and electricity infrastructure deployment. International Organization, 60(1), 263-286.

Jacobs, D. (2008). A review of capital budgeting practices. (IMF Working Paper No. 08/160), Washington, DC: International Monetary Fund.

Keefer, P., \& Knack, S. (2002). Polarization, politics and property rights: Links between inequality and growth. Public choice, 111(1-2), 127-154.

Kneller, R., Bleaney, M. F., \& Gemmell, N. (1999). Fiscal policy and growth: Evidence from OECD countries. Journal of Public Economics, 74(2), 171-190.

Leruth, L., \& Paul, E. (2006). A principal-agent theory approach to public expenditure management systems in developing countries (IMF WP/06/204). Washington, DC: International Monetary Fund.

Loizides, J., \& Vamvoukas, G. (2005). Government expenditure and economic growth: Evidence from trivariate causality testing. Journal of Applied Economics, 8(1), 125-152.

Mandl, U., Dierx, A., \& Ilzkovitz, F. (2008). The effectiveness and efficiency of public spending (No. 301). Directorate General Economic and Monetary Affairs (DG ECFIN), European Commission.

Mihaiu, D. M., Opreana, A., \& Cristescu, M. P. (2010). Efficiency, effectiveness and performance of the public sector. Romanian Journal of Economic Forecasting, 4(1), 132-147.

Moe, T. M. (1984). The new economics of organization. American Journal of Political Science, 28(4), 739-777.

Pesaran, M. H., Shin, Y., \& Smith, R. J. (2001). Bounds testing approaches to the analysis of level relationships. Journal of Applied Econometrics, 16(3), 289-326.

Rajaram, A., Le, T. M., Biletska, N., \& Brumby, J. (2010). A diagnostic framework for assessing public investment management (World Bank Policy Research Working Paper No. 5397). Washington, DC: World Bank Group.

Reinikka, R., \& Jakob, S. (2004). Local capture: Evidence from a central government transfer program in Uganda. Quarterly Journal of Economics, 119(2), 679-705.

Romer, P. M. (1997). Endogenous technological change. Journal of Political Economy, 98(5), Part 2, S71-S102.

Stock, J. H., \& Watson, M. W. (1993). A simple estimator of cointegrating vectors in higher order integrated systems. Econometrica, 61(4), 783-820.

Vietnamese Government. (2005). Law No. 59/2005/QH11 on investment (in Vietnamese). Retrieved from 
http://vanban.chinhphu.vn/portal/page/portal/chinhphu/hethongvanban?class_id=1\&mode=detail \&document_id=29555

Vietnamese Government. (2009). Decree No. 113/2009/ND-CP on investment monitoring and evaluation. Retrieved from http://thuvienphapluat.vn/van-ban/Dau-tu/Decree-No-113-2009-NDCP-of-December-15-2009-on-investment-monitoring-and-evaluation-101456.aspx

Vo, V. C. (2013). Checking and monitoring public investment in Vietnam (in Vietnamese). Journal of Development and Integration, 12(22), 54-61.

Weber, R., \& Singh, R. (1997). The composition of public expenditure and economic growth: Can anything be learned from Swiss data? Swiss Journal of Economics and Statistics, 133(III), 617634.

Weisbrod, B. (1988). The nonprofit economy. Cambridge, MA: Harvard University Press.

World Bank Group. (2001). World Bank development indicators. Washington, DC: World Bank Group.

World Bank Group. (2004). Haiti: Public expenditure management and financial accountability review. Washington, DC: World Bank Group.

Ye, Xiao, \& Sudharshan Canagarajah (2002). Efficiency of public expenditure distribution and beyond: A report on Ghana's 2000 public expenditure tracking survey in the sectors of primary health and education (Africa Region Working Paper Series No. 31). Washington, DC: World Bank Group.

Zagler, M., \& Durnecker, G. (2003). Fiscal policy and economic growth. Journal of Economic Surveys, 17(3), 397-418. 